\title{
On the possibility of using ion-exchange filters for water treatment
}

\author{
Tatiana Germanova ${ }^{1, *}$ \\ ${ }^{1}$ Industrial University of Tyumen, Institute of service and sectoral management, 625000, Russia, \\ Tyumen, Volodarskogo, 38
}

\begin{abstract}
This study was conducted with the aim of preliminary assessment of the total use of the working exchange capacity of cationexchangers during ion-exchange filtration of surface waters. The chemical composition of natural waters in Russia depends on many factors, which affects the performance indicators during operation of water treatment equipment. Comparison of geochemical indicators of natural waters of the Ob River basin at specific locations of water withdrawal in the Ural Federal District of Russia was carried out. For several compositions of natural waters, the calculation of two-stage ion-exchange filtration in the water treatment scheme for heat and power plants has been carried out. The possibility of rational use of ion-exchange filtration at the first stage of water purification and low efficiency of the use of ion-exchange filtration at the second stage of filtration for these plants is shown.
\end{abstract}

\section{Introduction}

Water supply for technological processes of heat and power equipment in most cases is provided by natural waters from surface sources. The chemical composition of river waters is not stable and depends on many factors, which affects the performance indicators in the operation of water treatment equipment. The purpose of this research was to identify the state of surface water and water-use problems during operation of heat and power equipment systems. To achieve the goal it is necessary to know the hydrochemical composition of natural waters and the requirements for water quality in accordance with the regulatory documentation in the field of heat and power equipment. The requirements are grouped for the quality of feed and make-up water, condensate and steam, and, accordingly, have distinctive qualitative and quantitative indicators. Upon receipt of softened water, an indicator of hardness in the source water and purified water is controlled. At the same time, for natural waters with the same hardness indicators during filtration, the same expected cleaning effect is not always achieved. This picture served as a guide to the selection of ionexchange water treatment equipment using the calculation method, taking into account the mineralization index for the Tobol River.

\footnotetext{
${ }^{*}$ Corresponding author: ecogtv@mail.ru
} 
To ensure the operation of energy supply systems, an important role is played by the calculated resource of water treatment equipment for certain components of the initial composition of the surface waters of rivers at the water intake site. With this in mind, it is expected that there will be a difference in the operating efficiency of equally selected water treatment schemes for various compositions of surface waters for a certain part of the territory. The correct choice of a water treatment plant plays an important role in ensuring the cost-effective and reliable operation of the heat and power equipment of the CHP plant. It is of interest to evaluate the efficiency of the application of the widely used method of water treatment - two-stage sodium cationization with different macrocomponent composition of surface water. This method is widely used due to its high efficiency and availability, low cost of regenerating materials. Thus, two-stage sodium cationization will be used to prepare water to compensate for steam and water losses at the Kurgan and Tyumen CHPs.

\section{Materials and methods}

The author reviewed the hydrochemical composition of the rivers of the Russian Federation. On the basis of literature data [1], the hydrochemical picture of the ionic composition of the main rivers of the European and East-Siberian part of Russia is presented (see figure). In the study of the hydrochemical composition of the country's natural waters, the features of natural surface waters in the Urals Federal District were revealed [2-5]. A comparative assessment of the hydrochemical parameters of a number of rivers: the ionic composition of the natural waters of the $\mathrm{Ob}$ River basin with identified differences in the classes of anions and cation groups was made [6]. By the calculation method according to the method presented in literature [7], the author estimated the hardness and alkalinity of the natural waters of the Ob River basin for the rivers: Irtysh, Ishim (see table 1).

Water treatment to compensate steam and water losses at the Kurgan and Tyumen CHP is carried out from surface sources: the Tobol River and the Tura River. A literary search for effective methods [8-30] showed that the ion-exchange method is widely used for water treatment and softening. The ion exchange method, a two-stage sodium-cation exchange, is also used in these enterprises.

Analysis of the existing requirements for water quality in accordance with the regulatory documentation and the capabilities of water treatment equipment for heat and power processes allowed the author to identify the water quality indicators necessary for the study. Rationing of water quality required an assessment of the content of various impurities in water and steam for technological processes in heat and power equipment (the analysis was performed in preparing the water to compensate for steam and water losses), and also its comparing with the level of water used for the Tobol River of the Kurgan Region. Selection of equipment using the calculation method for water treatment by the ion-exchange method makes it possible to identify how the salinity index influences the obtaining of the required level of water softening depending on the macrocomponent composition of surface water [7]. To analyze the correct selection of water treatment equipment, depending on the macrocomponent composition of the water supply source, the Kurgan CHP-2 site was chosen as the most complex in the composition of surface waters [2, 31, 32]. Calculations of water treatment equipment are made on the basis of two steam recovery boilers (SRB) with a capacity of $108 \mathrm{t} / \mathrm{h}$. 


\section{Results}

Analysis of the hydrochemical composition of rivers [1,2] of Russia shows the complex and distinctive composition of water in such territories as: Stavropol Territory, Republic of Bashkortostan, Arkhangelsk Oblast, Kurgan Oblast, south of the Tyumen Oblast. The chemical composition of natural waters (atmospheric, river, bog) is not stable and depends on many factors. The reasons for the differences in the mineralization of the rivers of the Russian Federation are the high moisture content of the catchments, the vast permafrost areas in the north, and in the south an increased dryness of climate and the soil rich in minerals. Basically, the composition of most rivers in the Russian Federation (see figure) is determined by the hydrocarbonate class according to the classification by O. A. Alekina [6]. According to the composition of the cations, they belong in almost all cases to the calcium group. Natural waters of the bicarbonate class occupy more than eighty percent of the entire territory of the Federation. Most of the natural waters of the hydrocarbonate class have low concentration (less than $200 \mathrm{mg} / \mathrm{l}$ ). They occupy most of the north of the European territory and the Asian territory of the country. A smaller area is occupied by river basins with waters of increased salinity (more than $500 \mathrm{mg} / \mathrm{l}$ ). They are distributed mainly in the south of the European part in the zones of forest-steppes and steppes. Natural bicarbonate waters with mineralization above $1000 \mathrm{mg} / \mathrm{l}$ in nature are extremely rare.

Rivers surface water of which belongs to the chloride class are rare. The predominance of natural waters belonging to the chloride class is observed mainly in the European territory (Stavropol Territory), in the south of the Tyumen, Kurgan and Novosibirsk regions and in the territory of Kazakhstan. The surface waters of the chloride class are characterized by high mineralization, mainly from 500 to $1000 \mathrm{mg} / \mathrm{l}$. A distinctive feature of the chloride class from others is the predominance of the sodium cation in natural water.

Rivers with natural water belonging to the sulphate class are relatively few in number. The predominance of natural waters belonging to the sulfate class is observed mainly in the European territory (Stavropol Territory, the Republic of Bashkortostan, the Arkhangelsk Region), but exceed the hydrocarbonate-class water in terms of salinity. Generally, the concentration of sulfates is from 500 to $1000 \mathrm{mg} / \mathrm{l}$, in rare cases from 200 to $500 \mathrm{mg} / \mathrm{l}$. Calcium is usually the predominant cation in the class presented.

As a result of hydrochemical analysis, it was determined that the rivers belonging to the chloride class are rarely found, similarly to rivers, in the surface waters of which sulfates predominate.

To determine the actual ionic composition of the rivers of the Ob River basin, various sources were analyzed in terms of initial water composition according to the macrocomponent attribute and a computational and analytical analysis of the hardness and alkalinity content (see Table 1).

Further we consider in more detail part of the territory of the Ural Federal District (see Fig). Here a diverse ionic composition of the Tobol River exists throughout its length. On the left bank of the river from the source to the mouth, a dynamic change in the ionic composition is seen: the sodium chloride class replaces the sulphate water class and then the bicarbonate water class with the calcium group. On the right bank, the situation is more stable: the class of chloride waters in surface waters mainly prevails and the amount of hydrocarbons increases only closer to the mouth of the river.

Thus, the presented analysis of surface waters shows a characteristic difference in the rivers of the $\mathrm{Ob}$ River basin in terms of salinity, total hardness and alkalinity. Increased overall hardness $(12.23 \mathrm{mg}$-equ/L) compared with other rivers is observed near the Ishim River. Chlorine $\mathrm{Cl}^{-}(26.53 \%)$ is the predominant anion, and $\mathrm{Na}^{+}$is the cation $(24.34 \%)$. 
Thus, the Ishim River belongs to the chloride class and the sodium group. There is a change in the macrocomponent composition of the $\mathrm{Ob}$ River. Mostly the predominant anions are bicarbonates (about $40 \%$ ), but at one site the predominant anions are $\mathrm{SO}_{4}{ }^{2}$ sulfates.

The effective use of a sorbent consists in the total use of its operating exchange capacity. Therefore, the use of the calculation method [7] for purification efficiency of the second stage of sodium cationization (sorbent cation-exchanger KU-2) and determining the boundaries of its application for different macrocomponent composition of surface waters in specific areas is an important task. To identify the efficiency of using this water treatment method from the three classes considered (chloride, sulphate, hydrocarbon) and two groups (calcium, sodium), the Tobol River surface water is presented with the following quality indicators (Table 1).

Table 1. The quality of the source water of the Tobol River

\begin{tabular}{|c|c|c|c|}
\hline № & Quality indicator & Measuring units & Value \\
\hline 1 & Sulphates & $\mathrm{mg} / \mathrm{dm}^{3}$ & 253 \\
\hline 2 & Chlorides & $\mathrm{mg} / \mathrm{dm}^{3}$ & 211 \\
\hline 3 & Total salt content & $\mathrm{mg} / \mathrm{dm}^{3}$ & 1099 \\
\hline 4 & Total hardness & $\mathrm{mg-equ} / \mathrm{dm}^{3}$ & 10.24 \\
\hline 5 & Ferrum total & $\mathrm{mg} / \mathrm{dm}^{3}$ & 0.2 \\
\hline 6 & Alkalinity & $\mathrm{mg-equ} / \mathrm{dm}^{3}$ & 5.16 \\
\hline 7 & Sodium-ion & $\mathrm{mg-equ} / \mathrm{dm}^{3}$ & 3.914 \\
\hline
\end{tabular}

To analyze the correct and rational selection of water treatment equipment, depending on the macro-component composition of the water supply source, the Kurgan CHP-2 site was chosen as the most complex in composition of surface waters. Calculations of water treatment equipment are made for two steam recovery boilers (SRB) with a capacity of $108 \mathrm{t} / \mathrm{h}$.

The water entering the sodium-cation-exchange filters of the second-stage should have a hardness $\mathrm{H}_{\mathrm{t}}=0.1 \mathrm{mg}$-equ $/ \mathrm{dm}^{3}$. The full cycle of two-stage water treatment for the sorbent was calculated after identifying the desired cleaning effect in terms of hardness for the second stage. The calculation used a widely recommended for this application method of calculation, in which the cleaning effect on the second filtration stage is determined by the ratio of $\mathrm{C}^{2} \mathrm{Na} / \mathrm{H}_{\mathrm{t}}$ concentrations [7]. The assessment of the total hardness after the first stage is also performed. Water with a content of $3.914 \mathrm{mg}$-equ/ $\mathrm{dm}^{3}$ of sodium cations enters the second stage of sodium cationization. 


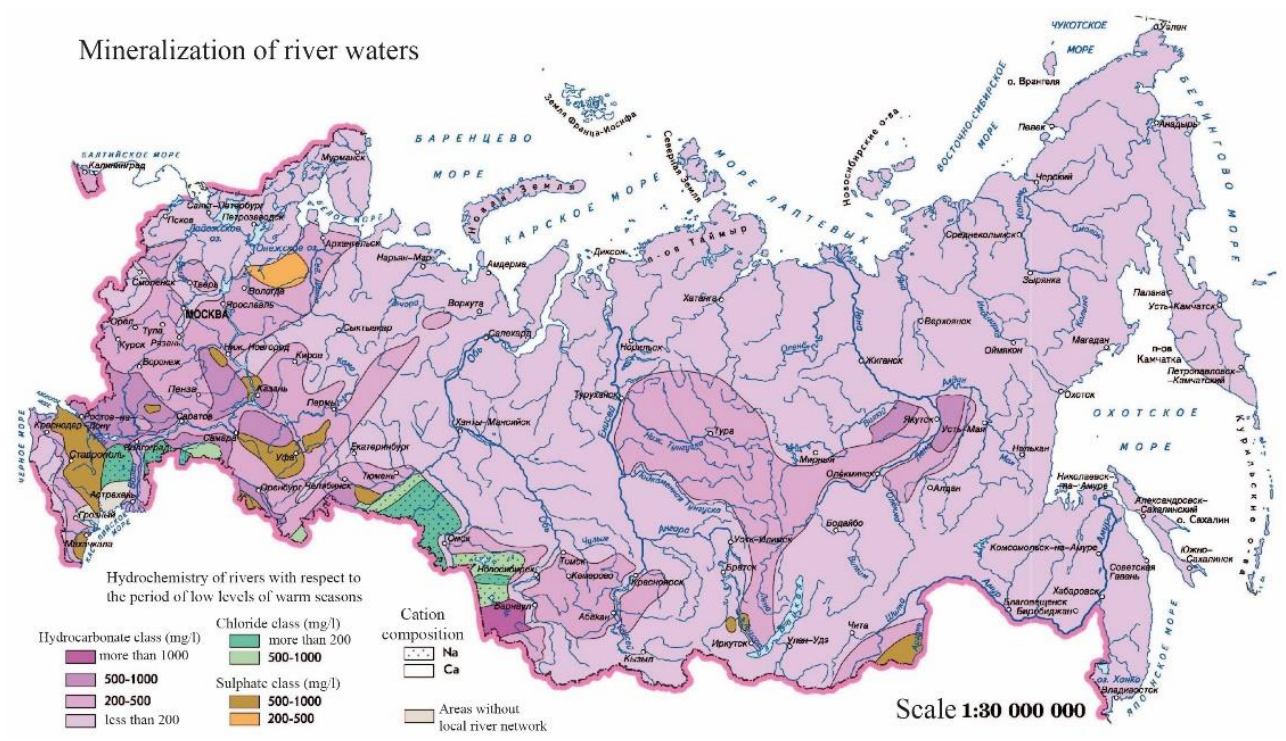

Fig. 1. Hydrochemical analysis of river waters at the territory of the Russian Federation

Table 2. Qualitative and quantitative assessment of composition of natural waters of the Ob River basin

\begin{tabular}{|c|c|c|c|c|c|c|c|c|c|c|c|c|}
\hline \multirow[b]{2}{*}{ N } & \multicolumn{4}{|c|}{ Cations } & \multicolumn{4}{|c|}{ Anions } & \multicolumn{3}{|c|}{$\begin{array}{l}\text { Hardness, mg- } \\
\text { equ/l }\end{array}$} & \multirow[b]{2}{*}{$\begin{array}{l}\text { Alkalin } \\
\text { ity, mg. } \\
\text { equ/1 }\end{array}$} \\
\hline & Indicator & $\mathrm{mg} / \mathrm{dm}^{3}$ & $\underset{3}{\mathrm{mg}-}$ & $\begin{array}{c}\text { Amount of } \\
\text { equivalent } \\
\text { substance, } \\
\%\end{array}$ & Indicator & $\mathrm{mg} / \mathrm{dm}^{3}$ & $\underset{3}{\mathrm{mg}-}$ & $\begin{array}{c}\text { Amount of } \\
\text { equivalent } \\
\text { substance, } \\
\%\end{array}$ & $\mathrm{H}_{\mathrm{t}}$ & $\mathrm{H}_{\mathrm{c}}$ & $\mathrm{H}_{\mathrm{nc}}$ & \\
\hline 1 & 2 & 3 & 4 & 5 & 6 & 7 & 8 & 9 & 10 & 11 & 12 & 13 \\
\hline \multicolumn{13}{|c|}{ Irtysh (1 sampling) [7] } \\
\hline & $\mathrm{Ca}^{2+}$ & 30.20 & 1.51 & 19.25 & $\mathrm{HCO}_{3}^{-}$ & 140 & 2.30 & 29.25 & \multirow{4}{*}{2.41} & \multirow{4}{*}{2.30} & \multirow{4}{*}{0.11} & \multirow{4}{*}{0.11} \\
\hline \multirow[t]{3}{*}{1} & $\mathrm{Mg}^{2+}$ & 10.80 & 0.90 & 11.47 & $\mathrm{Cl}^{-}$ & 19.00 & 0.54 & 6.82 & & & & \\
\hline & $\mathrm{Na}^{+}$ & 39.00 & 1.70 & 21.61 & $\mathrm{SO}_{4}^{2-}$ & 41.50 & 0.86 & 11.02 & & & & \\
\hline & $\mathrm{Fe}^{2+}$ & - & - & - & $\mathrm{NO}_{3}^{-}$ & 2.80 & 0.05 & 0.58 & & & & \\
\hline \multicolumn{13}{|c|}{ Irtysh (2 sampling) [7] } \\
\hline \multirow{4}{*}{2} & $\mathrm{Ca}^{2+}$ & 28.10 & 1.41 & 13.81 & $\mathrm{HCO}_{3}^{-}$ & 165.00 & 2.70 & 26.59 & \multirow{4}{*}{2.82} & \multirow{4}{*}{2.70} & \multirow{4}{*}{0.12} & \multirow{4}{*}{0.12} \\
\hline & $\mathrm{Mg}^{2+}$ & 17.00 & 1.42 & 13.93 & $\mathrm{Cl}^{-}$ & 84.00 & 2.37 & 23.26 & & & & \\
\hline & $\mathrm{Na}^{+}$ & 36.10 & 1.57 & 15.43 & $\mathrm{SO}_{4}{ }^{2-}$ & 31.70 & 0.66 & 6.49 & & & & \\
\hline & $\mathrm{Fe}^{2+}$ & - & - & - & $\mathrm{NO}_{3}^{-}$ & 3.00 & 0.05 & 0.48 & & & & \\
\hline & \multicolumn{12}{|c|}{ Ishim [7] } \\
\hline \multirow{4}{*}{3} & $\mathrm{Ca}^{2+}$ & 80.16 & 4.01 & 10.23 & $\mathrm{HCO}_{3}^{-}$ & 402.60 & 6.60 & 16.84 & \multirow{4}{*}{12.23} & \multirow{4}{*}{6.60} & \multirow{4}{*}{5.63} & \multirow{4}{*}{5.63} \\
\hline & $\mathrm{Mg}^{2+}$ & 98.68 & 8.22 & 20.98 & $\mathrm{Cl}^{-}$ & 369.20 & 10.40 & 26.53 & & & & \\
\hline & $\mathrm{Na}^{+}$ & 219.42 & 9.54 & 24.34 & $\mathrm{SO}_{4}^{2-}$ & 20.35 & 0.42 & 1.08 & & & & \\
\hline & $\mathrm{Fe}^{2+}$ & - & - & - & $\mathrm{NO}_{3}{ }^{-}$ & - & - & - & & & & \\
\hline
\end{tabular}

Note: $\mathrm{Ht}$ is total hardness, $\mathrm{H}_{\mathrm{c}}$ is carbonate hardness, $\mathrm{H}_{\mathrm{nc}}$ is non-carbonate hardness

Then the mentioned ratio will be the following: 3.9142/0.1 $=153$. When the ratio between the squared concentration of the $\mathrm{Na}^{+}$cations and the total hardness in the source water reaches a value greater than 10 , the working capacity decreases by more than fifty percents. In this case, bringing water to the required quality and evaluating the efficiency of operation of the equipment by the calculation method becomes difficult. 


\section{Discussion}

The calculations on the use of sodium-cation-exchange filters for a given composition of surface water showed that the water softening effect depends on the initial concentration of sodium $\mathrm{Na}+$ according to the group of the predominant surface water cation. The obtained calculated ratio is more than 10 , and, therefore, the use of sodium-cationite filters of the second stage to reduce the overall hardness in water is not advisable. The reduction of the exchange capacity of the cation exchanger for calcium cations $\mathrm{Ca} 2+$ and magnesium $\mathrm{Mg} 2+$ is performed due to the partial retention of sodium cations $\mathrm{Na}+$. The working exchange capacity of the cation exchanger is not used for a significant amount of volume. Efficient application of water softening on sodium-cationite filters of the second stage is possible with a certain initial concentration of sodium. Therefore, the process of water softening through ion-exchange resins using the second stage for Kurgan CHP-2 water, belonging to the sodium group of the sodium group, is not rational and is accompanied by inefficient resource and energy costs.

\section{Conclusions}

The use of the sodium-cationic method for softening natural waters belonging to the chloride group of the sodium group is not rational. The required amount of retention of calcium $\mathrm{Ca}^{2+}$ and magnesium $\mathrm{Mg}^{2+}$ cations with the available initial concentrations of $\mathrm{Na}+$ cations is not achieved. Efficient application of the second stage of sodium-cation-exchange filters for surface waters of the hydrocarbonate class is possible only for a certain concentration of sodium cations. The results are recommended to be used in organizations and enterprises specializing in the selection of water treatment equipment for sources of heat and electricity.

\section{References}

1. A. Klochko, Nacional'nyj atlas Rossii, Vol. 2 (Priroda i jekologija, Moscow, 2004)

2. Kachestvo poverhnostnyh vod Rossijskoj Federacii, Ezhegodnik-2016. 20-525 (2017)

3. T. Germanova, V. Nefedov, I. Valieva, IOP Conference Series: Earth and Environmental Science 66(1), 012011 (2017)

4. I. Valieva, T. Germanova, V. Nefedov, IOP Conference Series: Earth and Environmental Science 115(1), 012027 (2018)

5. Ja. Zubkevich, O. Bujakevich, G. Kachalova, E. Kazanceva, JOP Sovremennye naukoemkie tehnologii 9, 59-60 (2013)

6. O.A. Alekin, Osnovy gidrohimii (Gidrometeoizdat, Leningrad, 1970)

7. O. Lifshic, Spravochnik po vodopodgotovke kotel'nyh ustanovok, $2^{\text {nd }}$ edition (Energia, Moscow, 1976)

8. N.A. Politayeva, Y.A. Smyatskaya, V.V. Slugin, Comptes Rendus de L'Academie Bulgare des Sciences 71(6), 766-771 (2018)

9. E.E. Mal'tseva, A.A. Blokhin, Y.V. Murashkin, M.A. Mikhaylenko, Russian Journal of Applied Chemistry 90(4), 528-532 (2017)

10. E.A. Bondarenko, Kh.V. Ilìna, M.Ju. Andrianova, A.N. Chusov, Magazine of Civil Engineering 68(8), 37-44 (2016)

11. A.V. Chechevichkin, N.I. Vatin, V.V. Samonin, M.A. Grekov, Magazine of Civil Engineering 76(8), 201-213 (2017) 
12. J.G. Bazarnova, N.A. Politayeva, S.G. Bozhuk, Proceedings of the 2017 International Conference "Quality Management, Transport and Information Security, Information Technologies", IT and QM and IS 2017, 8085865, 471-476 (2017)

13. S. Moran, An Applied Guide to Water and Effluent Treatment Plant Design (Elsevier, Amsterdam, 2018)

14. S. Tarleton, Progress in Filtration and Separation (Academic Press, Cambridge, 2015)

15. S. Basu, A.K. Debnath, Power Plant Instrumentation and Control Handbook (Academic Press, Cambridge, 2015)

16. S. Parkash, Refining. Processes Handbook (Gulf Professional Publishing, Houston, 2003)

17. R. Singh, Membrane Technology and Engineering for Water Purification (Second Edition), (Butterworth-Heinemann, Oxford, 2015)

18. D. Ratnayaka, M.J. Brandt, K.M. Johnson, Water Supply (Sixth Edition) (ButterworthHeinemann, Oxford, 2009)

19. D. Sarkar, Thermal Power Plant (Elsevier, Amsterdam, 2015)

20. Selected Papers Presented at the Symposium on Progress in Ion Exchange. 4 (2), 67180 (1986)

21. Ion exchange and adsorbent precoat filters for treating toxic wastes. 4(2), 131-146 (1986)

22. I.D. Wilson, Water treatment. Ion Exchange. Encyclopedia of Separation Science (Academic press, Cambridge, 2000)

23. J.R. Couper, W.R. James, R.F. Stanley, M. Walas, Chemical Process Equipment (Third Edition) (Butterworth-Heinemann, Oxford, 2012)

24. S.-Y. Pan, S.W. Snyder, A.I. Packman, Y.J. Lin, P.-C. Chiang, Water-Energy Nexus 1(1), 26-41 (2018)

25. J.R. Couper, W.R. Penney, J.R. Fair, S.M. Walas, Chemical Process Equipment (Revised Second Edition) (Gulf Professional Publishing, Houston, 2010)

26. C. Luca. Organic Ion Exchangers. Encyclopedia of Separation Science. 1617-1632 (Academic Press, Cambridge, 2000)

27. N.P. Chandrasekara, R.M. Pashley, Separation and Purification Technology 158, 16-23 (2016)

28. S. Maruyama, F. Krause, S. Filho, A. Leitão, F. Wypych, Applied Clay Science 146, 100-105 (2017)

29. Z. Berk, Food Process Engineering and Technology (Third Edition) (Academic Press, Cambridge, 2018)

30. I. Levchuk, J. Márquez, M. Sillanpää, Chemosphere 192, 90-104 (2018)

31. A. Koeva, S. Maksimova, G. Kachalova, JOP Sovremennye naukoemkie tehnologii 5(1), 47-50 (2014).

32. Severnyj morskoj put', vodnye i suhoputnye transportnye koridory kak osnova razvitija Sibiri i Arktiki v XXI veke. 60-65 (2018) 